\title{
Anthropogenic influences on hydrocarbon contents of sediments deposited in eastern Lake Ontario since 1800
}

\author{
R. A. Bourbonniere - P. A. Meyers
}

\begin{abstract}
The amounts and types of extractable hydrocarbon components in sediment cores from the Rochester Basin of eastern Lake Ontario provide a record of environmental changes that have accompanied the settlement and population growth of the surrounding land areas. Sediments deposited prior to the mid-1800s contain low concentrations of hydrocarbons that are dominated by land-plant wax components. Concentrations begin to rise in the late 1800 s as erosion of soil and nutrients from watershed areas accelerated. This pattern continues into modern times. Episodes of enhanced aquatic productivity are sometimes recorded in twentiethcentury sediments by the dominance of algal hydrocarbons, but land-plant components typically predominate. Petroleum residues begin to appear in sediments deposited in the late 1800's but remain minor constituents of the hydrocarbon contents of modern sediments in the Rochester Basin.
\end{abstract}

Key words Organic carbon $\cdot n$-Alkanes

Petroleum residues · Sediments · Lake Ontario

\section{Introduction}

The hydrocarbon fraction of organic matter in modern lake sediments is a combination of biologically synthesized components, other compounds derived from diagenetic alterations of biological matter, and anthropogenically derived materials, principally petroleum residues (Wakeham 1977a, b; Meyers 1987; Meyers and Ishiwatari

Received: 21 March 1995 - Accepted: 11 August 1995

\section{R. A. Bourbonniere}

Environment Canada, National Water Research Institute, Burlington, Ontario L7R 4A6, Canada

\section{P. A. Meyers (四)}

Department of Geological Sciences and Center for Great Lakes and Aquatic Sciences, The University of Michigan, Ann Arbor, Michigan 48109-1063, USA
1993). Hydrocarbons introduced to lake sediments tend to have long residence times for two seasons. First, higher-molecular-weight hydrocarbon components have relatively low water solubilities and vapor pressures and consequently associate strongly with sediment particles. Second, hydrocarbons as a group are less susceptible to degradation than most forms of organic matter because they lack the functional groups that impart chemical reactivity.

Hydrocarbon biomarker compounds and their distributions have proved useful in studies of the histories of organic matter accumulations in lake sediments. Differences in aquatic productivity are recorded in the types and amounts of hydrocarbons incorporated into lake sediments and by their degree of diagenetic reworking (Cranwell 1978, 1981; Cranwell and Volkman 1981; Kawamura and Ishiwatari 1985). Because hydrocarbon molecules are relatively more resistant to diagenetic modifications than other forms of organic matter, they provide long-lived indications of changes in sources of organic matter to lake systems (e.g., Giger and others 1980; Prahl and Carpenter 1984; Meyers and Ishiwatari 1993).

Hydrocarbon studies of sediment cores from Lakes $\mathrm{Hu}-$ ron, Erie, and Ontario have revealed evidence of paleodepositional changes in the Laurentian Great Lakes (Meyers and others 1980; Meyers and Takeuchi 1981; Eadie and others 1991; Bourbonniere and Meyers 1996). Of particular prominence are the human impacts associated with conversion of the lake watershed from forested land to farm land and with more recent cutcural eutrophication. Moreover, sediments from Saginaw Bay of Lake Huron record the advent of the use of petroleum within the watershed starting ca 1850 (Meyers and Takeuchi 1981). Surficial sediments of Lakes Erie, St. Clair, and Ontario provide a record of contaminant dispersion in their hydrocarbon contents (Nagy and others 1984). We report here hydrocarbon depositional records of two sediment cores from the Rochester Basin of Lake Ontario.

\section{Sampling and analysis}

Sediment coring and dating

Sediment samples from Lake Ontario were obtained from stations E30 and G32 in the Rochester Basin of Lake On- 


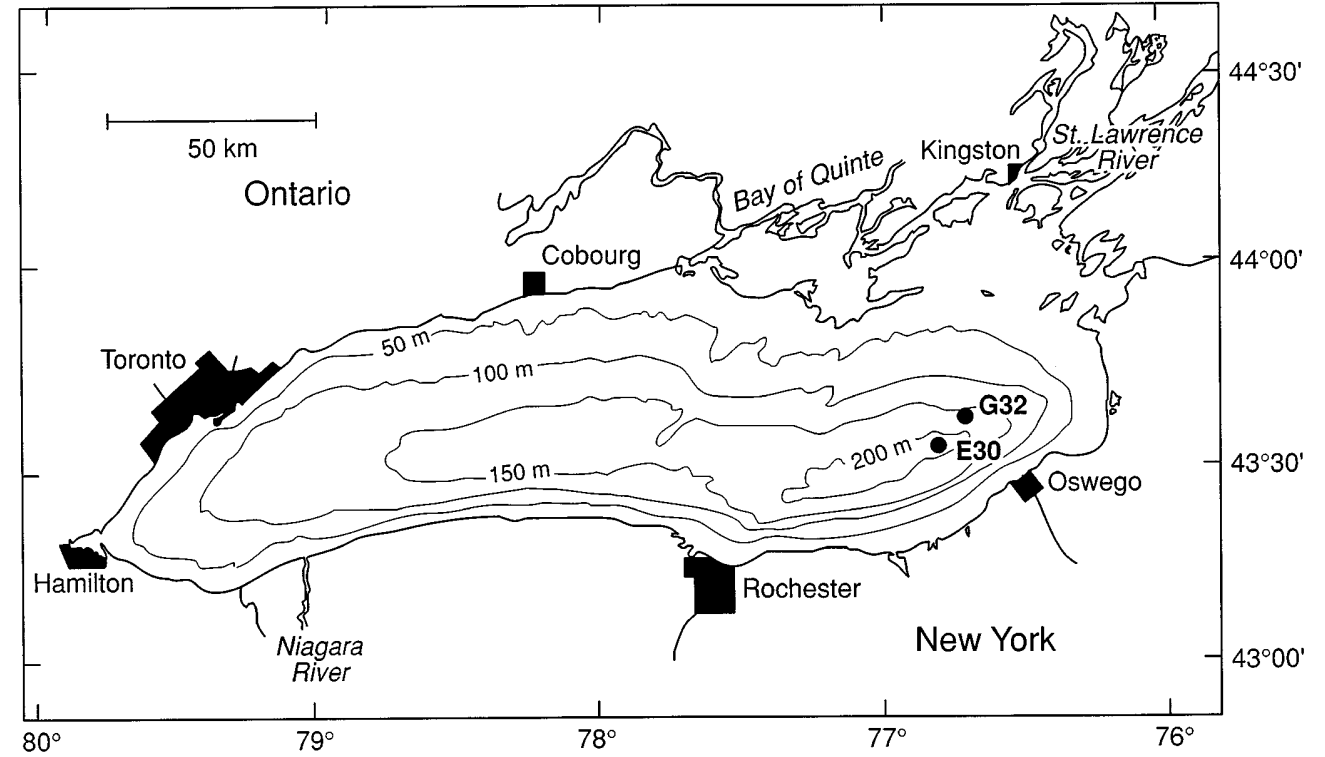

Fig. 1

Locations of coring stations in the Rochester Basin of Lake Ontario. Bathymetric contours are in meters. The water depths of stations E30 and G32 in Lake Ontario are $223 \mathrm{~m}$ and $158 \mathrm{~m}$, respectively. Sediment cores were dated by ${ }^{210} \mathrm{~Pb}$ radiochronology (Eisenreich and others 1989) tario (Fig. 1) in 1981. The water depths at these locations are 233 and $158 \mathrm{~m}$, respectively. A $40 \mathrm{~m}$ box corer $(50 \mathrm{~cm}$ square) was used to obtain undisturbed samples of the upper sediment record. Subcores from the box corer were sectioned on board ship by vertical hydraulic extrusion into $1-\mathrm{cm}$ intervals down to $20 \mathrm{~cm}$ and $2-\mathrm{cm}$ intervals from 20 to $40 \mathrm{~cm}$. A $1.7-\mathrm{m}$-long Benthos 7.5-cm-diameter gravity corer was used to sample deeper sediments. Sediment was similarly extruded vertically from the Benthos gravity corer and sectioned into $1-\mathrm{cm}$ intervals immediately after collection. Sections from both corers were frozen in solvent-cleaned glass jars on board ship and were freeze-dried within three months of collection. Sediment sections were weighed before and after drying to obtain cumulative dry weights.

Companion subcores from the box cores were dated by the ${ }^{210} \mathrm{~Pb}$ methods used by Robbins and coworkers on Great Lakes cores (e.g. Robbins and Edgington 1975). The excess ${ }^{210} \mathrm{~Pb}$ contents of the sediments were applied to a steady-state mixing model to determine sediment accumulation rates (Eisenreich and others 1989). Approximate deposition dates were assigned to each section of the cores using the mass sedimentation rates previously reported from companion cores - E30: $0.0443 \mathrm{~g} \mathrm{~cm}^{-2} \mathrm{y}^{-1}$; G32: $0.0767 \mathrm{~g} \mathrm{~cm}^{-2} \mathrm{y}^{-1}$ (Eisenreich and others 1989) and the cumulative dry weights for the present cores. Data are presented relative to deposition dates rather than core depths to facilitate discussion and comparison between the two sites.

Cores from both of these locations exhibit sediment mixing due to bioturbation, which indicates that the bottom waters have remained oxygenated. The mixing is less at the deeper station, E30, than at G32 and differentially integrates the sediment accumulation of a single year over a multi-year depth. The temporal resolution of near-surface sediments is consequently ca $11 \mathrm{yr}$ at station E30 and ca $13 \mathrm{yr}$ at station G32 (Eisenreich and others 1989).

\section{Organic carbon analysis}

Organic carbon concentrations were determined by dry combustion of carbonate-free sediment samples at $1000^{\circ} \mathrm{C}$ in a Leco IR-12 carbon analyzer. Carbonate was removed from intact dried sediment by treatment with concentrated sulfurous acid. Replicate analyses routinely agreed within a relative $3 \%$. Organic carbon concentrations are reported on a whole-sediment basis.

\section{Lipid extraction and analysis}

Geolipids were Soxhlet-extracted with a 1:1 mix of toluene and methanol, partitioned, saponified, and methylated (Leenheer and others 1984). Saturated hydrocarbon fractions were isolated on alumina over silica chromatography columns. They were analyzed with a Carlo-Erba 4160 gas chromatograph equipped with on-column injection and a 30-m fused silica capillary column coated with SE30. Quantification of individual hydrocarbon components was achieved using internal standards added before extraction and FID response factors determined using quantitative mixtures of known compounds. Unresolved complex mixtures (UCMs) of hydrocarbons were quantified manually with a polar planimeter. Data have been corrected for the small amounts of procedural contaminants determined by blank analyses.

\section{Results and discussion}

There are three distinctive, principal sources of hydrocarbons to the sediments of modern lakes. First, the hydrocarbon compositions of photosynthetic algae and bacteria are dominated by the $\mathrm{C}_{17} n$-alkane (e.g., Blumer and others 1971; Giger and others 1980; Cranwell and others 1987). Second, hydrocarbons contributed from vascular plants on land or along the edges of lakes contain large proportions of $\mathrm{C}_{27}, \mathrm{C}_{29}$, and $\mathrm{C}_{31} n$-alkanes, which origi- 
nate in the epicuticular waxy coatings of these plants (e.g., Eglinton and Hamilton 1963, 1967; Cranwell 1973; Cranwell and others 1987; Rieley and others 1991). Finally, petroleum residues are common in the sediments of lakes near urban and suburban areas (Wakeham 1977a; Meyers 1987). Petroleum hydrocarbons can be distinguished from biological hydrocarbons by two distinctive characteristics: (1) absence of the characteristic odd-carbon-number chain-length dominance of biological hydrocarbons, and (2) presence of a more diverse range of molecular structures than is found in biological hydrocarbon mixtures. This latter characteristic results in a mixture of hydrocarbon compounds that cannot be separated even by high-resolution capillary gas chromatography, giving rise to the term "unresolved complex mixture" or UCM. Sediments of Lake Ontario provide a historic record of change in sources of hydrocarbons, which in turn record historical changes in the lake and watershed ecosystems. Early settlement and forest clearance by European settlers in the mid-19th century produced an increase in lake productivity, which is marked by enhanced silica and organic carbon delivery to lake sediments (Schelske and others 1983, 1988). Urbanization of the watershed and construction of sewage treatment systems after 1940 dramatically increased delivery of nutrients to the lake. Organic carbon delivery doubled and inorganic carbon accumulation increased by a factor of ten (Schelske and others 1988; Schelske and Hodell 1991). These alterations of the earlier, pristine lake system left their imprints on the hydrocarbon composition of lake sediments.

\section{Sediment accumulation rates}

The radiometrically determined linear sedimentation rates from the two locations differ, with the result that the ages of the basal sediments recovered by the $40-\mathrm{cm}$ box corer are different. The deeper station has a lower accumulation rate and consequently longer sediment record. The approximate ages of the oldest box core sediments are 1800 at station E30 and 1870 at station G32. Mass accumulation rates in Lake Ontario have not been constant over the periods of depositional history recorded in the cores. Schelske and others (1988) determined that the rates increased by ca $40 \%$ at station E30 and ca $30 \%$ at station G32 since the early part of this century. These increases are postulated to result partially from enhancements of aquatic productivity since the mid to late 1800s (Schelske and others 1983, 1988; Schelske and Hodell 1991) and partially from progressively more land erosion resulting from continued growth of human populations within the watersheds of the Great Lakes (Bourbonniere and Meyers 1996). These changes have also impacted accumulation of organic matter over these time periods.

\section{Organic carbon records}

Concentrations of organic carbon are elevated in the more recently deposited sediments and decrease with depth of burial (Fig. 2). The upper sediment intervals from stations E30 and G32 in Lake Ontario have concen-

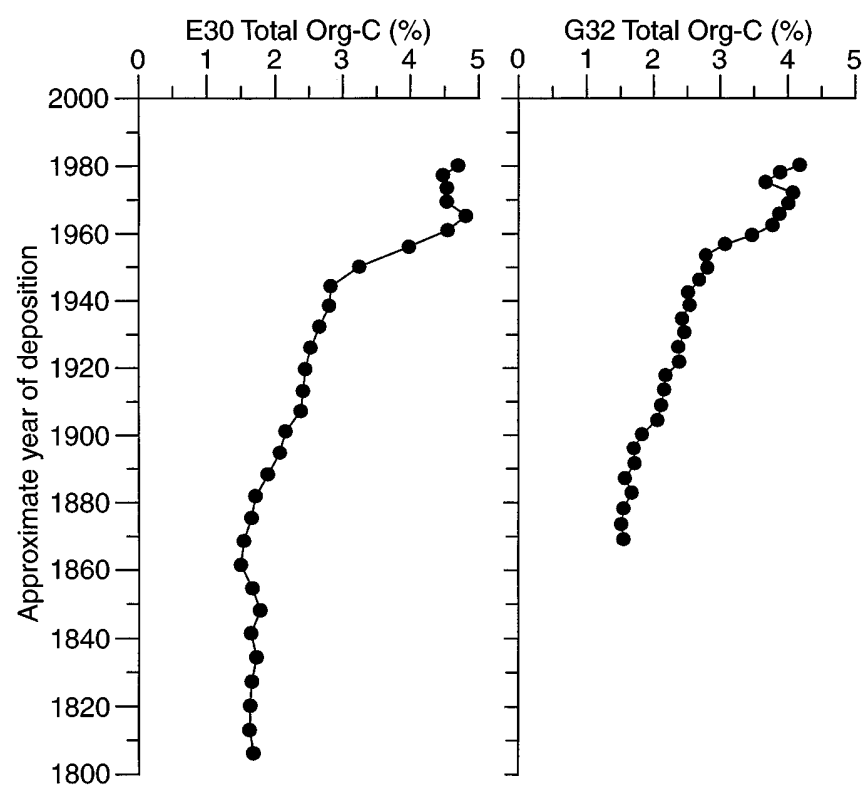

Fig. 2

Total organic carbon (TOC) concentrations in sediments of stations E30 and G32, Lake Ontario. Values of 1-cm intervals from the top $20 \mathrm{~cm}$ and of $2-\mathrm{cm}$ intervals from 20 to $40 \mathrm{~cm}$ subbottom are plotted against year of deposition

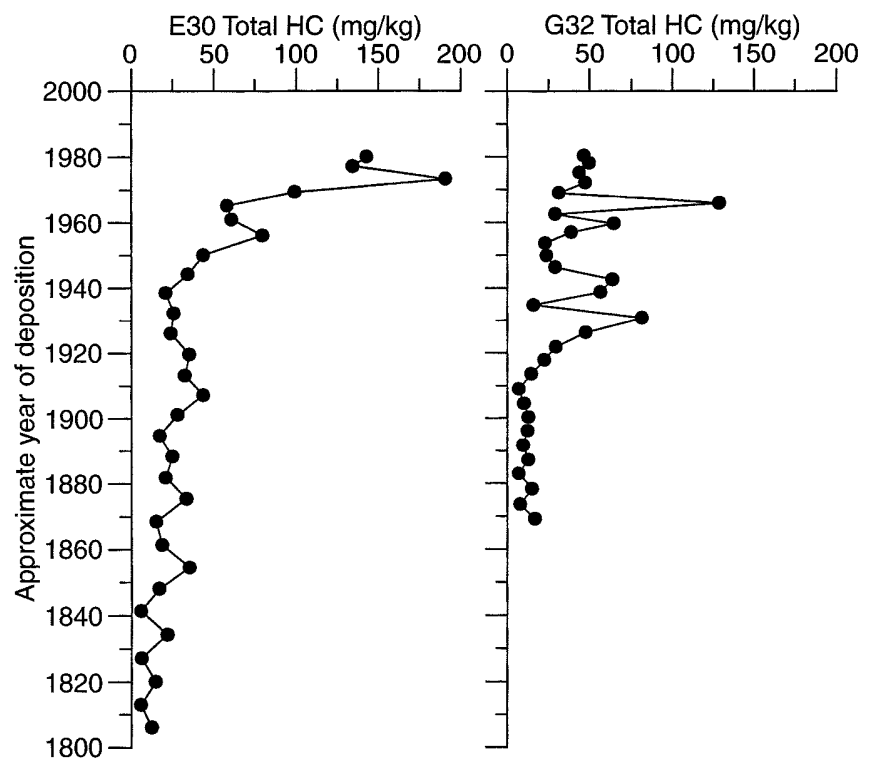

Fig. 3

Total extractable hydrocarbon contents of sediments from stations E30 and G32, Lake Ontario. Values of 1-cm intervals from the top $20 \mathrm{~cm}$ and of $2-\mathrm{cm}$ intervals from 20 to $40 \mathrm{~cm}$ subbottom are plotted against year of deposition

trations between 4 and 5\%, whereas deeper sediments contain $1.5-2 \%$ organic carbon.

The organic carbon records in both cores indicate important changes in organic matter deposition. The Lake Ontario watershed was deforested for agriculture between 1820 and 1850 (Schelske and others 1983). The removal of forest cover resulted in increased delivery of dissolved 
phosphorus from land to the lake, enhancing aquatic productivity. Schelske and others (1988) note that organic carbon concentrations in these Lake Ontario cores follow the increases in phytoplankton abundance expected from the phosphorus enrichments. Organic carbon levels in sediments gradually increased in response to the higher productivity until about 1950. After this, postwar growth of urban and suburban areas greatly enhanced nutrient delivery to the Great Lakes, causing a marked increase in both aquatic productivity and the rate of carbon accumulation.

\section{Extractable hydrocarbon records}

Concentrations of extractable hydrocarbons vary through the records of organic matter deposition provided by the sediment cores, yet an unmistakable trend towards higher values in recent sediments is apparent at both sites (Fig. 3 ). The variability may originate partially from either numerous short-term changes in the hydrocarbon content of organic matter or from fluctuations in the amounts of hydrocarbons that are preserved in the sedimentary record. The second possibility is unlikely, because studies of relative apparent decomposition rates of organic matter settling in Lake Michigan show that hydrocarbons degrade two to three times slower than does total organic matter (Meyers and Eadie 1993). Moreover, the record of total organic carbon accumulation in these two cores is less variable than the hydrocarbon record and consequently fluctuations in hydrocarbon preservation cannot be an important cause of the variability seen in Fig. 3. Instead, these hydrocarbon accumulation records indicate that the proportions of hydrocarbons in the deposited organic matter have fluctuated and have increased in the source materials. Schelske and Hodell (1991) have noted a correspondence between carbon isotope contents, years of early onset of thermal stratification, and enhanced algal productivity in the sedimentary record at station G32 in Lake Ontario. Environmental fluctuations of this type can potentially affect the supply of organic matter to the sediments, even though their record is integrated over the temporal resolutions of the core intervals. These postulated fluctuations may similarly impact the proportions of hydrocarbons in the sedimentary records of Lake Ontario. The trend towards increasing concentrations of hydrocarbons beginning ca 1930 in both cores (Fig. 3) evidently records progressively greater delivery of hydrocarbons from watershed sources.

Further evidence that watershed sources are the major controls on the hydrocarbon loadings of recent sediments is implied by the concentration patterns reported by Nagy and others (1984). Highest concentrations ( $>1000 \mathrm{mg} \mathrm{kg}^{-1}$ sediment) exist near the entrance of the Detroit River to western Lake Erie and evidently reflect industrial contributions. In contrast, the average hydrocarbon concentration for sediments of Lake Ontario is ca $100 \mathrm{mg} \mathrm{kg}^{-1}$. The value that Nagy and others (1984) find for the Rochester Basin, $126 \mathrm{mg} \mathrm{kg}^{-1}$ is very close to the surficial concentration we measured at station E30 $\left(140 \mathrm{mg} \mathrm{kg}^{-1}\right)$. Because total extractable hydrocarbon

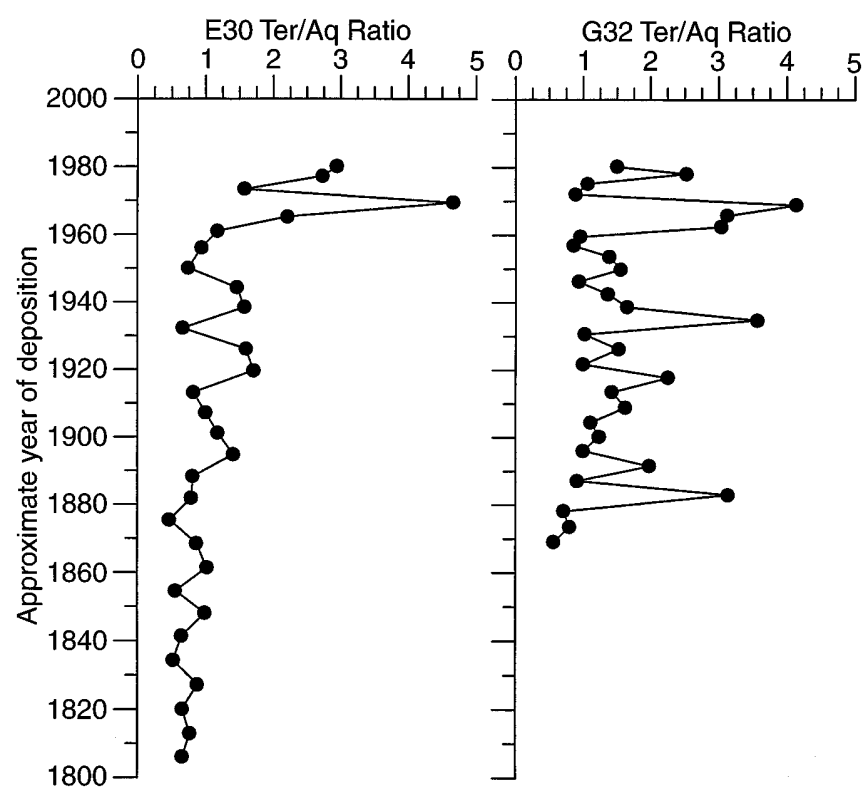

Fig. 4

Ratios of terrigenous $\left(\mathrm{C}_{27}+\mathrm{C}_{29}+\mathrm{C}_{31}\right)$ to aquatic $\left(\mathrm{C}_{15}+\mathrm{C}_{17}+\mathrm{C}_{19}\right)$ $n$-alkanes in sediments from stations E30 and G32, Lake Ontario. Values of $1-\mathrm{cm}$ intervals from the top $20 \mathrm{~cm}$ and of 2 -cm intervals from 20 to $40 \mathrm{~cm}$ subbottom are plotted against year of deposition

concentrations were determined by Nagy and others (1984) using infrared spectrophotometry, molecular evidence of their sources is not available.

\section{Changes in contributions of biological hydrocarbons}

The relative contributions of the suite of individual $n$-alkanes included in the total extractable hydrocarbon fractions can provide information about the biological sources of these geolipids. We employed a ratio of these biomarker $n$-alkane source indicators to investigate possible changes in the terrigenous/aquatic mixture of hydrocarbons in these cores of Great Lakes sediment. The ratios of terrigenous to aquatic $n$-alkanes were estimated as: terrigenous/aquatic ratio $(\mathrm{TAR})=\left(\mathrm{C}_{27}+\mathrm{C}_{29}+\mathrm{C}_{31}\right)$ / $\left(C_{15}+C_{17}+C_{19}\right)$. Higher values for this parameter indicate increased watershed sources of lipid matter relative to aquatic sources.

The $n$-alkane TAR is generally larger than 1 and quite variable in all the cores for sediments deposited since the beginning of the 1900s, but it is less than 1 and less variable in the older sedimentary record available from Lake Ontario (Fig. 4). Contributions of land-derived organic matter typically contain higher proportions of $n$-alkanes than do those from aquatic algae, and consequently parameters like the TAR overrepresent the absolute amounts from terrigenous sources (cf. Cranwell and others 1987; Goossens and others 1989). This ratio nonetheless is valuable for determining changes in relative contributions of organic matter from land and lake flora. The contrast between the low TAR values in older sediments and the higher and more variable values since the 


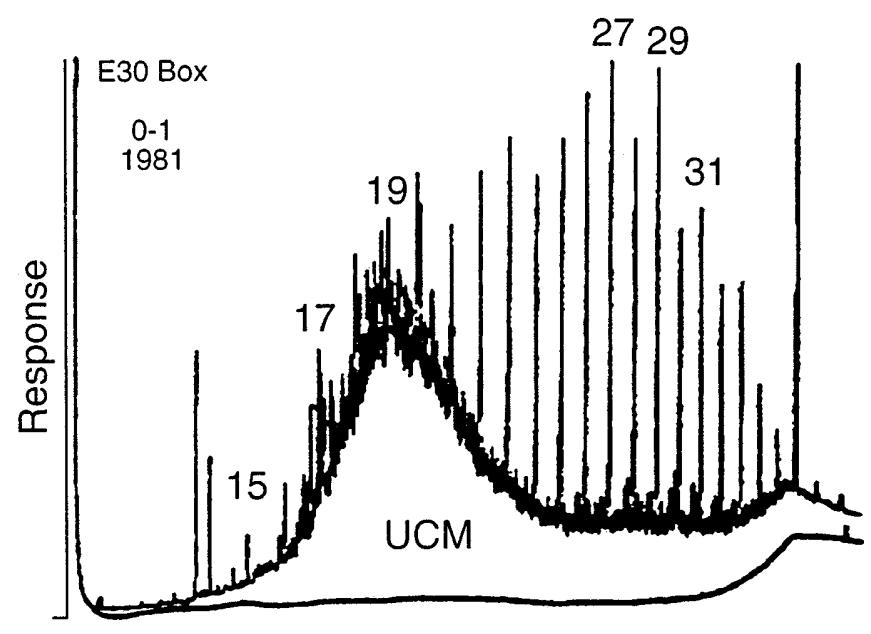

Time

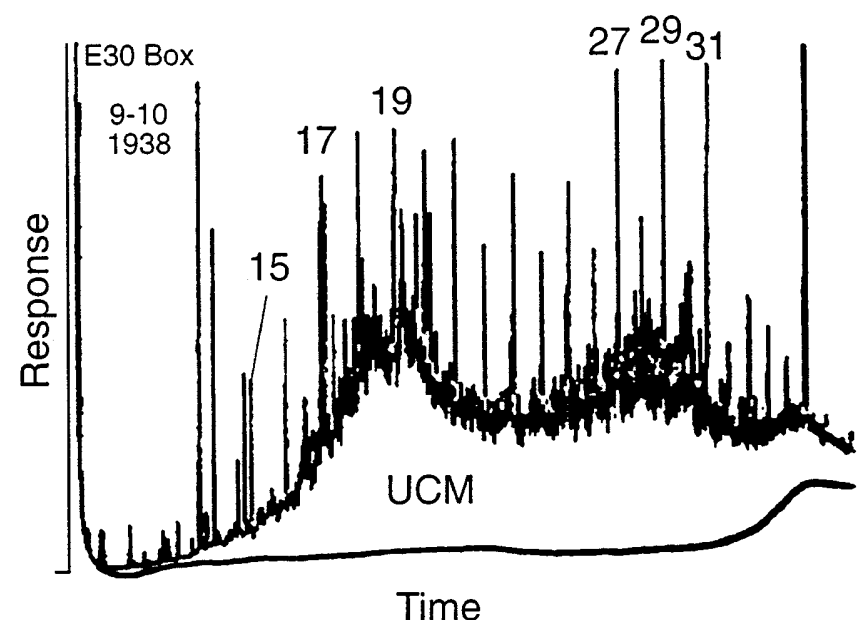

Fig. 5

Chromatograms of total hydrocarbons extracted from four representative core intervals from station E30. Numbers identify chain lengths of individual $n$-alkanes. UCM indicates the unresolved complex mixture of petroleum hydrocarbons. The 50 - to $55-\mathrm{cm}$ interval represents pristine lake conditions

beginning of this century reflects a change in geolipid sources. The twentieth-century Lake Ontario sediments record progressively larger pulses of land-derived hydrocarbon delivery to this lake. This pattern reflects the increasingly urbanized character of the watershed, which has accelerated land runoff from paved roadways and from domestic wastewaters. Paradoxically, this factor has also increased nutrient supply to the lake flora and has caused eutrophication (e.g., Schelske and others 1983; Schelske and Hodell 1991). The low TAR values interspersed among the high twentieth-century values probably record periods of enhanced algal production, inasmuch as organic carbon accumulation increases continually since ca 1870 (Fig. 2). The isotopic shift to more recent heavier $\delta^{13} \mathrm{C}$ values (Schelske and Hodell 1991) shows that aquatic productivity in Lake Ontario has indeed increased over this period of sediment accumulation.

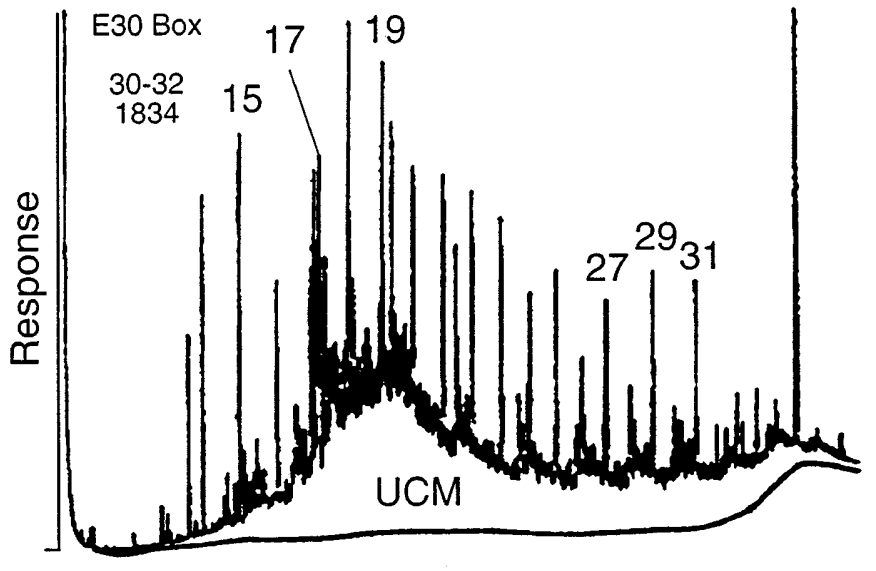

Time

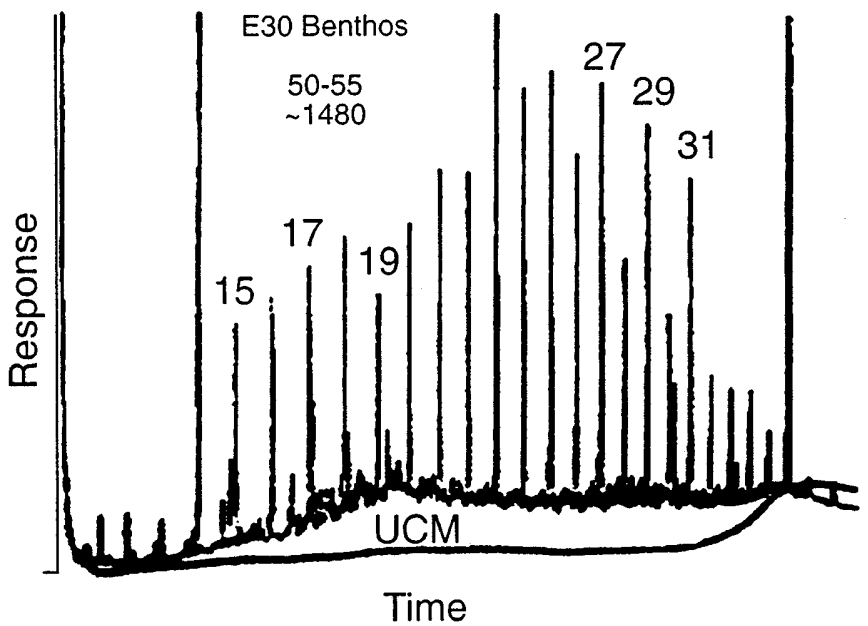

Hydrocarbons in general are less susceptible to microbial destruction during and after sedimentation than are most other types of organic matter (e.g., Prahl and Carpenter 1984; Meyers and Eadie 1993; Meyers and others 1995), and the terrigenous long-chain hydrocarbons are less likely to be destroyed than are the short-chain algal hydrocarbons (Giger and others 1980; Cranwell 1984). Where preservation of organic matter is enhanced, the presence of larger amounts of normally degraded organic matter fractions diminishes the hydrocarbon proportions. At the same time, enhanced preservation of algal $n$-alkanes depresses TAR values. The TAR values of ca 1 in pre-1880 sediments in Lake Ontario reflect small contributions of terrigenous $n$-alkanes during the originally oligotropic conditions of the Great Lakes.

\section{Record of petroleum hydrocarbon contamination}

The presence of petroleum hydrocarbons in modern sediments of the Rochester Basin is shown by the large UCM proportion in the chromatogram of surficial sediments from station E30 (Fig. 5). The size of the UCM component remains large in sediments deposited since 1900, and gradually becomes smaller in older core sections. It is a minor contribution to the total hydrocarbons in sediments at 50-55 cm (Fig. 5), which represent pristine, pre- 


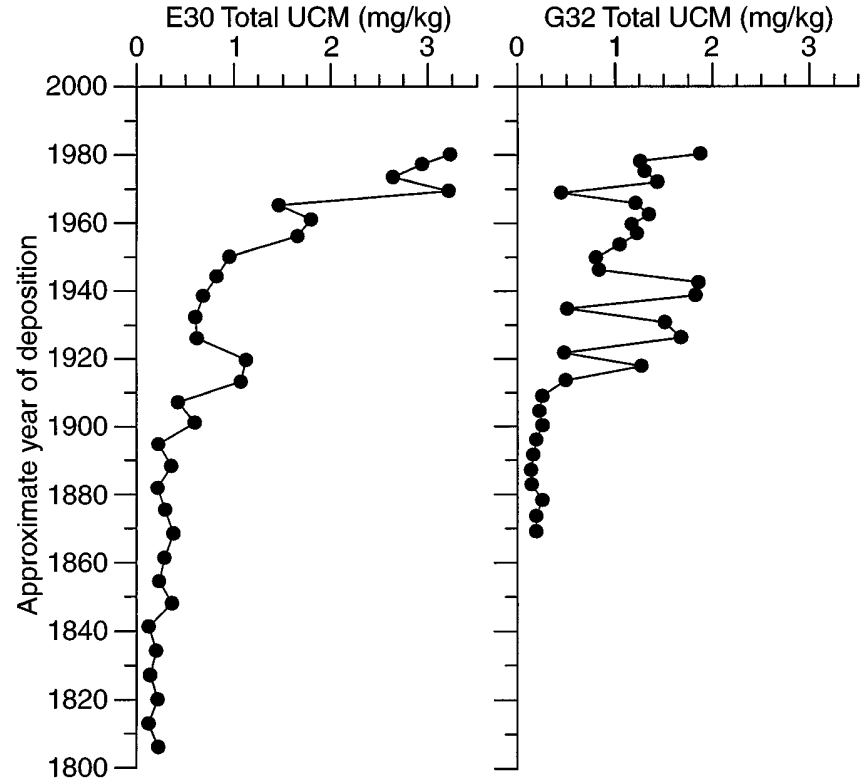

Fig. 6

Changes in concentrations of the unresolved complex mixture (UCM) of petroleum residue hydrocarbons at different intervals in the depositional records at stations G32 and E30 in the Rochester Basin of Lake Ontario

European settlement conditions of the Lake Ontario watershed.

The history of petroleum hydrocarbon accumulation in sediments of eastern Lake Ontario is summarized by the downcore UCM concentration profiles at stations E30 and G32 (Fig. 6). Concentrations at both locations are highest in surface sediments and decrease irregularly with depth, becoming minor in core intervals deposited prior to ca 1880. These profiles mirror the change in UCM contribution to sediments of Saginaw Bay, Lake Huron, reported by Meyers and Takeuchi (1981). Diagenetic degradation of the petroleum residues in older sediments is unlikely to be an important contribution to these profiles inasmuch as hydrocarbons are relatively unreactive forms of organic matter. The downcore patterns of decreasing UCM concentrations consequently reflect a progressive proportional increase in petroleum hydrocarbon contributions to the biological hydrocarbon accumulations in the modern sediments of these lake areas.

A variety of sources undoubtedly contributes to the petroleum hydrocarbons that have accumulated in the sediments of the Rochester Basin. Direct inputs of fuels, lubricants, and partially combusted fuels from commercial and recreational vessels on the lake and its tributary rivers are probable. Suspended solids in wastewater effluent carry petroleum residues that can settle out and accumulate in bottom sediments (Van Vleet and Quinn 1977). The major source, however, is likely to be stormwater runoff from paved roadways in the drainage basin. Wakeham $(1977 \mathrm{a}, \mathrm{b})$ determined that approximately $85 \%$ of the petroleum hydrocarbons found in the sediments of Lake Washington were delivered as runoff. The UCM profiles in Fig. 6 evidently record the chronic, nonpoint source input of petroleum residues to Lake Ontario beginning about 110 years ago and continuing to the present.

The pattern of increasing delivery of petroleum residues is mimicked in part by delivery of anthropogenic lead and polycyclic aromatic hydrocarbons to the sediments of the Rochester Basin. Graney and others (1995) document an increase in lead concentrations starting soon after the introduction of leaded gasoline in 1930. This increase eventually reaches six times the delivery of lead from natural sources before decreasing since use of leaded gasoline has been curtailed. The similarities between the petroleum and lead increases suggests a common linkage in residues from automobile exhausts. An important difference, however, is that petroleum usage pre- and postdates the use of lead tetraethyl in gasoline, and this is apparent in the appearance of hydrocarbon increases beginning in the late 1800 s and increasing to recent sediments (Fig. 6). Eadie and others (1991) show that the sediment burden of combustion-derived polycyclic aromatic hydrocarbons begins to increase in the late 1800 s as the regional economy changes from an agricultural society to an industrial one. Concentrations of these hydrocarbons diminish rapidly in sediments deposited after the mid-1900s as coal was replaced by petroleum as the principal energy source. Moreover, an important difference between the delivery records of the anthropogenic materials and of natural hydrocarbons is that biological components dominate the hydrocarbon compositions throughout the histories of accumulation at both Rochester Basin sites.

\section{Summary and conclusions}

Our comparison of the hydrocarbon contents of sediments from two locations in the Rochester Basin of Lake Ontario shows that these components provide information about the aspects of the changes in the watershed and aquatic ecosystems of this lake. A summary of our findings is:

1. Sediment organic carbon concentrations and hydrocarbon compositions record progressively greater delivery of organic matter to the lake as a result of human disturbances to the ecosystems of the lake and watershed. Eutrophication, deforestation, and urbanization have been major influences.

2. Petroleum hydrocarbon residues began to be introduced into the lake starting in the late 1800's. These nonbiological hydrocarbons started to accumulate in the sediments of the Rochester Basin beginning around 1880 and have continued to increase in concentration.

3. Despite the record of increasing petroleum burden, these Lake Ontario sediments are not heavily contaminated. Petroleum residues comprise only a few percent of the hydrocarbon contents and only a few tenths of a percent of the total organic matter of modern Rochester Basin sediments. 
Acknowledgements Support for coring and geolipid analyses was provided by Environment Canada, National Water Research Institute. This study was conducted in cooperation with the HISED Project of the Great Lakes Environmental Research Laboratory, US National Oceanic and Atmospheric Administration. Radiochronology was done by J. A. Robbins as part of the HISED Project. We thank the captain and the crew of CSS Limnos and members of the NWRI Technical Operations Division for their skill and help in obtaining the box cores used in this study. Laboratory assistance by T. Mayer, L. O'Conner, A. Risk, and $\mathrm{B}$. Treen is greatly appreciated. We acknowledge the donors of the Petroleum Research Fund, administered by the American Chemical Society, for partial support of this research.

\section{References}

Blumer M, Guillard RRL, and Chase T (1971) Hydrocarbons of marine plankton. Mar Biol 18:183-189

Bourbonniere RA and Meyers PA (1996) Sedimentary geolipid records of historical changes in the watersheds and productivities of Lakes Ontario and Erie. Limnol Oceanogr (in press)

CRANWELl PA (1973) Chain-length distribution of $n$-alkanes from lake sediments in relation to post-glacial environmental change. Freshwater Biol 3:259-265

Cranwell PA (1978) Extractable and bound lipid components in a freshwater sediment. Geochim Cosmochim Acta 42:1523-1532

Cranwell PA (1981) Diagenesis of free and bound lipids in terrestrial detritus deposited in a lacustrine sediment. Org Geochem 3:79-89

Cranwell PA (1984) Lipid geochemistry of sediments from Upton Broad, a small productive lake. Org Geochem 7:25-37

Cranwell PA and Volkman JK (1981) Alkyl and steryl esters in a recent lacustrine sediment. Chem Geol 32:29-43

Cranwell PA, Eglinton G, and Robinson N (1987) Lipids of aquatic organisms as potential contributors to lacustrine sediments - II. Org Geochem 11:513-527

EAdie BJ, Robbins JA, Faust WR, and LANdrum PA (1991) Polycyclic aromatic hydrocarbons in sediments and pore waters of the lower Great Lakes: Reconstruction of a regional benzo(a)pyrene sourc function. In: Baker RA (Ed), Organic substances in sediments and water, $\mathrm{Vol} 2$, processes and analysis. Washington, DC: American Chemical Society. pp 171190

Eisenreich SJ, CAPel PD, Robbins JA, and Bourbonniere RA (1989) Accumulation and diagenesis of chlorinated hydrocarbons in lacustrine sediments. Environ Sci Technol 23: $1116-1126$

Eglinton G and Hamilton RJ (1963) The distribution of alkanes. In: Swaine T (Ed), Chemical plant taxonomy. New York: Academic press. pp 187-217

EgLinton G and Hamilton RJ (1967) Leaf epicuticular waxes. Science 156:1322-1335

Giger W, Schaffner C, and Wakeham SC (1980) Aliphatic and olefinic hydrocarbons in recent sediments of Greifensee, Switzerland. Geochim Cosmochim Acta 44:119-129

Goossens H, Duren C, De Leeuw JW, and Schenck PA (1989) Lipids and their mode of occurrence in bacteria and sediments - II. Lipids in the sediment of a stratified, freshwater lake. Org Geochem 14:27-41
Graney JR, Halliday AN, Keeler GJ, Nriagu JO, Robbins JA, and Norton SA (1995) Isotopic record of lead pollution in lake sediments from the northeastern United States. Geochim Cosmochim Acta 59:1715-1728

KAWAMURA K and Ishiwatari R (1985) Distribution of lipidclass compounds in bottom sediments of freshwater lakes with different trophic status, in Japan. Chem Geol 51:123-133

Leenheer MJ, Flessland KD, and Meyers PA (1984) Comparison of lipid character of sediments from the Great Lakes and the northwestern Atlantic. Org Geochem 7:141-150

Meyers PA (1987) Chronic contamination of lakes by petroleum hydrocarbons: The sedimentary record, In: Vandermeulen JH and Hrudy SE (Eds), Oil in freshwater: Chemistry, biology, countermeasure technology. New York: Pergamon Press. pp 149-160

Meyers PA and Eadie BJ (1993) Sources, degradation, and recycling of organic matter associated with sinking particles in Lake Michigan. Org Geochem 20:47-56

Meyers PA and Ishiwatari R (1993) Lacustrine organic geochemistry - an overview of indicators of organic matter sources and diagenesis in lake sediments. Org Geochem $20: 867-900$

Meyers PA and Takeuchi N (1981) Environmental changes in Saginaw Bay, Lake Huron, recorded by geolipid contents of sediments deposited since 1800. Environ Geol 3:257-266

Meyers PA, Bourbonniere RA, and Takeuchi N (1980) Hydrocarbons and fatty acids in two cores of Lake Huron sediments. Geochim Cosmochim Acta 44:1215-1221

Meyers PA, Leenheer MJ, and Bourbonniere RA (1995) Diagenesis of vascular plant organic matter components during burial in lake sediments. Aquatic Geochem 1:36-52

Nagy E, Mudroch P, Mudroch A, and Thomas RL (1984) Hydrocarbons in the surficial sediments of Lakes St. Clair, Erie, and Ontario. Environ Geol Water Sci 6:31-37

Prahl FG and Carpenter R (1984) Hydrocarbons in Washington coastal sediments. Estuarine Coastal Shelf Sci 18:703720

Rieley G, Collier RJ, Jones DM, and Eglinton G (1991) The biogeochemistry of Ellesmere Lake, UK - I: Source correlation of leaf wax inputs to the sedimentary lipid record. Org Geochem 17:901-912

Robbins JA and Edgington DN (1975) Determination of recent sedimentation rates in Lake Michigan using $\mathrm{Pb}-210$ and Cs-137. Geochim Cosmochim Acta 39:285-304

Schelske CL and Hodell DA (1991) Recent changes in productivity and climate of Lake Ontario detected by isotopic analysis of sediments. Limnol Oceanogr 36:961-975

Schelske CL, Stoermer EF, Conley DJ, Robbins JA, and Glover RM (1983) Early eutrophication in the Lower Great Lakes: New evidence from biogenic silica in sediments. Science 222:320-322

Schelske CL, Robbins JA, Gardner WS, Conley DJ, and BourbonNiere RA (1988) Sediment record of biogeochemi$\mathrm{cal}$ responses to anthropogenic perturbations of nutrient cycles in Lake Ontario. Can J Fish Aquatic Sci 45:1291-1303

VAN VLeET ES and QUINN JG (1977) Input and fate of petroleum hydrocarbons entering the Providence River and Upper Narragansett Bay from wastewater effluents. Environ Sci Technol 11:1086-1092

WAKEHAM SG (1977a) A characterization of the sources of petroleum hydrocarbons in Lake Washington. J Water Pollut Control Fed 49:1680-1687

WAKEHAM SG (1977b) Hydrocarbons budgets for Lake Washington. Limnol Oceanogr 22:952-957 